\title{
Tropical forest soil microbial communities couple iron and carbon biogeochemistry
}

Eric A. Dubinsky ${ }^{1}$, Whendee L. Silver and Mary K. Firestone ${ }^{1 *}$

Ecosystem Sciences Division, Department of Environmental Science, Policy, and Management, University of California, Berkeley, CA 94720

*Lawrence Berkeley National Laboratory, Berkeley, CA 94720

${ }^{1}$ Present address: Ecology Department, Lawrence Berkeley National Laboratory, 1 Cyclotron Rd., MS 70A-3317, Berkeley, CA 94720. E-mail: eadubinsky@lbl.gov 


\begin{abstract}
We report that iron-reducing bacteria are primary mediators of anaerobic carbon oxidation in upland tropical soils spanning a rainfall gradient $\left(3500-5000 \mathrm{~mm} \mathrm{yr}^{-1}\right)$ in northeast Puerto Rico. The abundant rainfall and high net primary productivity of these tropical forests provide optimal soil habitat for iron-reducing and iron-oxidizing bacteria. Spatially and temporally dynamic redox conditions make iron-transforming microbial communities central to the belowground carbon cycle in these wet tropical forests. The exceedingly high abundance of iron-reducing bacteria (up to $1.2 \times 10^{9}$ cells per gram soil) indicated that they possess extensive metabolic capacity to catalyze the reduction of iron minerals. In soils from the higher rainfall sites, measured rates of ferric iron reduction could account for up to $44 \%$ of organic carbon oxidation. Iron reducers appeared to compete with methanogens when labile carbon availability was limited. We found large numbers of bacteria that oxidize reduced iron at sites with high rates of iron reduction and large numbers of iron-reducers. The coexistence of large populations of ironreducing and iron-oxidizing bacteria is evidence for rapid iron cycling between its reduced and oxidized states, and suggests that mutualistic interactions among these bacteria ultimately fuel organic carbon oxidation and inhibit $\mathrm{CH}_{4}$ production in these upland tropical forests.
\end{abstract}

\title{
Keywords
}

Bacteria, carbon cycling, iron reduction, Luquillo Mountains, methanogenisis, microbial ecology, Puerto Rico, tropical forest soils 


\section{Introduction}

Humid tropical forests account for an estimated $35 \%$ of global plant productivity and 20 $\%$ of global soil organic carbon (C) storage (Jobbagy and Jackson 2000, Saugier et al. 2002). Highly-weathered soils found in much of the humid tropics contain high concentrations of iron (Fe) and aluminum (Al) oxides that strongly influence the bioavailability of nutrients and $\mathrm{C}$ (Sanchez 1976, Uehara and Gillman 1981). Adsorption to metal oxide surfaces is a major reservoir for soil phosphorus $(\mathrm{P})$ and organic $\mathrm{C}$ that is not readily accessible to plants and microbes. Constraints on nutrients and $\mathrm{C}$ availability imposed by metal oxides may limit productivity in tropical forests and influence the capacity of soils in these ecosystems to store C (Herbert and Fownes 1995, Torn et al. 1997, Vitousek and Farrington 1997).

When oxygen $\left(\mathrm{O}_{2}\right)$ availability is limiting, some bacterial taxa can transform Fe oxide minerals by rapidly reducing ferric iron [Fe(III)] (Lovley et al. 2004). Microbial reduction releases ferrous iron $[\mathrm{Fe}(\mathrm{II})]$ into solution as well as $\mathrm{P}$ and $\mathrm{C}$ that are sorbed or occluded by Fe(III) oxides (Patrick and Khalid 1974, Chacón et al. 2006, Wagai and Mayer 2007).

Dissimilatory $\mathrm{Fe}(\mathrm{III})$-reduction by bacteria can also play a central role in decomposition and trace gas emissions from soil. In some environments where $\mathrm{Fe}(\mathrm{III})$ oxides are abundant and $\mathrm{O}_{2}$ is scarce, the anoxic oxidation of $\mathrm{C}$ is due almost entirely to the reduction of $\mathrm{Fe}$ (III) by bacteria (Canfield et al. 1993, Roden and Wetzel 1996, Neubauer et al. 2005). In addition, Fe(III)reducers can suppress methane $\left(\mathrm{CH}_{4}\right)$ production by competing for acetate and hydrogen with methanogenic archaea (Lovley and Phillips 1987, Achtnich et al. 1995, Frenzel et al. 1999, Chidthaisong and Conrad 2000, Teh et al. 2008).

Upland tropical soils in high-rainfall areas may be ideal habitats for Fe-cycling bacteria. There is great potential for anaerobic and microaerobic microbial activity in humid tropical soils 
due to high biological $\mathrm{O}_{2}$ demand that is fueled by available $\mathrm{C}$ and persistently warm and wet conditions. Soil $\mathrm{O}_{2}$ concentrations can fluctuate between near atmospheric to anoxic over short time scales (hours to days) and distances (meters) (Silver et al. 1999). In addition, large quantities of poorly-crystalline Fe(III) minerals that are amenable to bacterial reduction have been found in humid tropical soils (Miller et al. 2001, Küsel et al. 2002, Peretyazhko and Sposito 2005) and are likely to be the most abundant electron acceptor for microbial respiration upon soil $\mathrm{O}_{2}$ depletion. The juxtaposition of both oxidizing and reducing conditions in these high $\mathrm{C}$, high Fe soils has potential to select for large numbers of Fe(III)-reducing and Fe(II)-oxidizing bacteria that may be centrally important to $\mathrm{C}$ and nutrient cycling in the humid tropics.

In this study we quantified the abundance and activity of Fe(III)-reducing bacterial communities in the rooting zone of three upland tropical forests that span an orographic rainfall gradient in northeast Puerto Rico. We determined Fe(III)-reduction rates and estimated the potential contribution of $\mathrm{Fe}(\mathrm{III})$-reducing bacteria to mineralization of organic matter and inhibition of $\mathrm{CH}_{4}$ production. We investigated the short-term response of $\mathrm{Fe}(\mathrm{III})$ reduction to labile $\mathrm{C}$ and electron shuttling quinones to determine whether inputs of labile $\mathrm{C}$ (through root exudates, DOC, and plant litter production) could accelerate Fe(III) reduction. We also quantified $\mathrm{Fe}(\mathrm{II})$-oxidizing bacteria, assessing their potential importance in replenishing $\mathrm{Fe}(\mathrm{III})$ to the $\mathrm{Fe}(\mathrm{III})$ reducing community; this mutualism could underlie the coupling of $\mathrm{Fe}$ and $\mathrm{C}$ processing in these tropical forest systems.

\section{Methods}

Site Description 
This study was conducted in the Luquillo Experimental Forest, an NSF Long Term Ecological Research site in northeastern Puerto Rico (Lat. 18³0’ N, 6580’ W), part of the NSF sponsored Long Term Ecological Research Program. Five sites were chosen in montane wet and rain forests sensu Holdridge (1967) that span an elevation gradient from 350 to 950 masl. Precipitation increases with elevation from $3500 \mathrm{~mm} \mathrm{yr}^{-1}$ to $5000 \mathrm{~mm} \mathrm{yr}^{-1}$ (including cloud input) and mean annual temperature decreases from $23^{\circ} \mathrm{C}$ to $19^{\circ} \mathrm{C}$ (Brown et al. 1983). The climate is relatively aseasonal with little monthly variability in precipitation and temperature (Brown et al. 1983, Scatena 1989). The lowest elevation is characterized as the tabonuco forest type (subtropical wet forest); we sampled from ridge (SWF-R) and valley floor (SWF-V) environments. At mid-elevation we sampled two sites in the colorado forest type (lower montane wet forest) (MWF-1, MWF-4), and at the highest elevation we sampled in a cloud forest (lower montane rain forest) (MRF). Site characteristics are shown in Table 1.

The steep and highly dissected terrain of the Luquillo Mountains is subject to some of the most intense weathering on the Earth's surface (White et al. 1998). Soils are derived from a bedrock of marine volcanoclastic sediments that contain quartz diorite intrusions. SWF soils are classified as parasesquic, isohyperthermic Typic Haplohumults; MWF soils are kaolinitic, isothermic Aquic Dystrudepts; and MRF soils are mixed, isomesic Humic Haplaquox (Huffaker 2002). Redoximorphic features such as mottling and gleying were observed in SWF-V, MWF and MRF soils and plaques of iron oxides on roots were observed in MRF soils.

Silver et al. (1999) characterized bulk soil $\mathrm{O}_{2}$ concentrations and $\mathrm{CH}_{4}$ fluxes in these forests over a 2-year period. Oxygen concentrations at $10 \mathrm{~cm}$ depth averaged $21 \% \mathrm{in} \mathrm{SWF}-\mathrm{R}$ soils, $10 \%$ in SWF-V soils, $13 \%$ in MWF soils and $8 \%$ in MRF soils. In all but the SWF-R soils, $\mathrm{O}_{2}$ concentrations were highly variable over time and conditions ranged from oxic to 


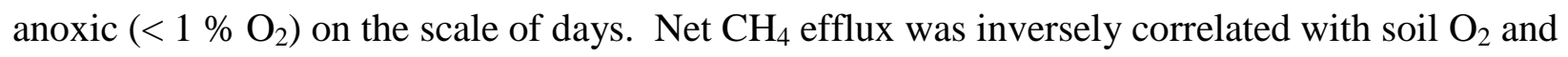
averaged -0.8 mg CH $4 \mathrm{~m}^{-2} \mathrm{~d}^{-1}$ in SWF-R soils, $4.6 \mathrm{mg} \mathrm{CH}_{4} \mathrm{~m}^{-2} \mathrm{~d}^{-1}$ in $\mathrm{SWF}-\mathrm{V}, 0.3 \mathrm{mg} \mathrm{CH}_{4} \mathrm{~m}^{-2} \mathrm{~d}^{-1}$ in MWF soils and $\mathrm{mg} 97.7 \mathrm{CH}_{4} \mathrm{~m}^{-2} \mathrm{~d}^{-1}$ in MRF soils.

Soil sampling and chemical analyses

Within each of the five forest types we sampled along three 10 meter long transects that were randomly placed at each site. Transects within a forest type were within an area of approximately $100 \mathrm{~m}^{2}$. Along each transect five $6 \mathrm{~cm}$ diameter soil cores from the primary rooting zone $(0-10 \mathrm{~cm}$ depth) were collected for rate measurements, five cores were collected for bacterial counts and experimental incubations, and five cores were collected for soil chemical and physical analyses. Intact soil cores were transported in sealed Ziploc bags at room temperature to the University of California, Berkeley and prepared for analysis within 24 hours after collection.

Five soil cores from each transect were homogenized and measured for gravimetric water content and $\mathrm{pH}$ in 1:1 slurry of deionized water. Samples used for all other chemical and physical analyses were pooled and homogenized by transect, freeze dried and sieved through a 20 mesh screen. Total Fe and Mn (hydr)oxides were measured in duplicate for each sample using a citrate-bicarbonate-dithionite extraction (Loeppert and Inskeep 1996). Poorly-crystalline Fe oxides were measured in duplicate using a citrate-ascorbate extraction (Reyes and Torrent 1997). Concentrations of Fe and Mn in these extracts were analyzed by inductively coupled plasma spectroscopy (PerkinElmer ICP-OES, Waltham, MA). Total C and N were measured on samples that were ground to a fine powder and analyzed with an automated nitrogen and carbon 
analyzer (PDZ Europa, Crewe, UK). Particle size analysis was conducted by the University of California ANR Analytical Laboratory (Davis, CA).

\section{Bacterial abundance}

All soils were enumerated for culturable bacteria that reduce Fe(III) directly or in the presence of an electron shuttling quinone, Anthraquinone-2,6-disulfonate (AQDS). AQDS is considered a humic acid analogue and contains quinone moieties that can be reduced by microorganisms for respiration, but is not readily decomposed as a source of C (Lovley et al. 1996). Microorganisms can transfer electrons to quinones in extracellular compounds, such as humic substances, which can then shuttle electrons to insoluble Fe(III) and regenerate the oxidized quinone for repeated bacterial reduction. Electron shuttling to Fe(III) via extracellular quinones can increase the reductive dissolution of both poorly-crystalline and crystalline $\mathrm{Fe}(\mathrm{III})$ oxides (Nevin and Lovley 2002).

Cell densities of $\mathrm{Fe}(\mathrm{III})$-reducing bacteria were estimated with a most probable number (MPN) analysis of composite samples that were homogenized by transect. Samples for MPN analysis were collected on two occasions in 2004 and 2006. Immediately upon arrival to the laboratory samples were prepared for analysis in an anaerobic chamber (Coy Laboratory Products, MI) with an $80 \% \mathrm{~N}_{2}+15 \% \mathrm{CO}_{2}+5 \% \mathrm{H}_{2}$ atmosphere. Each initial dilution $\left(10^{-1}\right)$ contained $50 \mathrm{~g}$ sample added to sterile medium supplemented with $0.1 \%$ Na-pyrophosphate and $0.03 \%$ Tween 80 to release cells bound to soil particles. Growth media contained acetate (10 $\mathrm{mM})$ as the electron donor and either poorly crystalline Fe(III) oxides (30 mM) or the soluble quinone AQDS $(100 \mu \mathrm{M})+$ amorphous Fe(III) oxides $(30 \mathrm{mM})$ as the electron acceptor(s). Poorly crystalline Fe(III) oxides were prepared as described by Schwertmann and Cornell (2000) 
and added to basal freshwater medium consisting of (in g/L): $\mathrm{NaCl}(1.0), \mathrm{MgCl}_{2} \cdot 6 \mathrm{H}_{2} \mathrm{O}(0.4)$, $\mathrm{CaCl}_{2} \cdot 2 \mathrm{H}_{2} \mathrm{O}(0.15), \mathrm{KH}_{2} \mathrm{PO}_{4}(0.2), \mathrm{KCl}(0.5), \mathrm{NH}_{4} \mathrm{Cl}(0.25)$. The medium was adjusted to $\mathrm{pH}$ 5.0, autoclaved, and supplemented with $1 \mathrm{~mL} / \mathrm{L}$ each of SL12 trace elements solution, vitamin solution (Pfennig and Trüper 1992), and selenite-tungstate solution (Widdel and Bak 1992). The medium was dispensed into 96-well microtiter plates and samples were serially diluted to a dilution of $10^{-11}$ with four replicates per dilution. Inoculated and negative-control plates were incubated anaerobically in the dark at room temperature for 60 days. Positive growth was visualized by adding ferrozine solution that turns purple in the presence of Fe(II). MPN estimates were calculated using the Most Probable Number Calculator version 4.04 (Klee 1996). Cell densities of lithotrophic Fe(II)-oxidizing bacteria were estimated with a MPN analysis of samples that were homogenized by site. Fe(II)-oxidizing bacteria were cultured in gradient tubes as described in Emerson and Moyer (1997) using ferrous sulfide as the Fe(II) source. Gradient tubes provide an environment with opposing gradients of $\mathrm{O}_{2}$ and $\mathrm{Fe}(\mathrm{II})$ to accommodate microaerophilic growth by Fe(II)-oxidizing bacteria. Serial dilutions to $10^{-9}$ with three replicates per dilution were made with modified Wolfe's mineral media (Emerson and Moyer 1997) and incubated in gradient tubes at room temperature for 90 days. A discrete band of oxidized $\mathrm{Fe}$ at the oxic-anoxic interface indicated positive growth.

Number of total microbial cells were enumerated by direct counts. Soils were diluted to $10^{-3}$ in $50 \mathrm{mM}$ filter sterilized $\mathrm{KHPO}_{4}$ buffer containing $0.1 \% \mathrm{Na}$-pyrophosphate and $0.03 \%$ Tween 80 . Cells were stained by adding $500 \mu \mathrm{L}$ of the diluted sample to $120 \mu \mathrm{L}$ SYTO-9 dye prepared from the LIVE/DEAD BacLight Bacterial Viability Kit (Invitrogen, Carlsbad, CA). Stained samples were incubated in the dark for 15 minutes, washed and added to a black polycarbonate membrane for counting. Digital images of stained samples were captured using 
an epiflourescence microscope and analyzed with the aid ImageJ version 1.38w (National Institutes of Health, USA).

\section{Rates of iron reduction and trace gas emissions}

Rates of Fe(III) reduction were estimated by measuring the amount of $\mathrm{Fe}(\mathrm{II})$ production in 24-hour anaerobic incubations. Intact soil cores were placed in an anaerobic glove bag with a $100 \% \mathrm{~N}_{2}$ atmosphere. Each soil core was split longitudinally. One half was immediately homogenized and duplicate 3 gram subsamples were added to $30 \mathrm{~mL}$ of $1 \mathrm{M} \mathrm{HCl}$ for an initial measurement of $\mathrm{Fe}(\mathrm{II})$. $\mathrm{Fe}(\mathrm{II})$ was extracted by shaking for 1-hour in $1 \mathrm{M} \mathrm{HCl}$ and filtering through a $0.22 \mu \mathrm{M}$ syringe filter. Fe(II) in the extract was measured colorimetrically using the ferrozine method (Stookey 1970); $100 \mu \mathrm{L}$ or $20 \mu \mathrm{L}$ (when [Fe(II)] > 1mM) of the filtrate was added to $2 \mathrm{~mL}$ ferrozine solution ( $1 \mathrm{~g} / \mathrm{L}$ ferrozine in $50 \mathrm{mM}$ HEPES buffer, $\mathrm{pH}$ 7.0). After 10 minutes, absorbance was measured with a spectrophotometer at a wavelength of $562 \mathrm{~nm}$.

The other half of the sample was weighed and sealed in a 1 quart mason jar equipped with a rubber septa for gas sampling. After 24 hours of anaerobic incubation at $25^{\circ} \mathrm{C}$ gas samples were collected with gastight syringes and stored in pre-evacuated $20 \mathrm{~mL}$ serum bottles sealed with butyl rubber septa (Geo-Microbial Technologies Inc., Ochelata, OK). At 24 h, soil samples were removed from jars in the anaerobic glove bag, homogenized and extracted for Fe(II). Gas samples were measured for $\mathrm{CO}_{2}$ and $\mathrm{CH}_{4}$ using a gas chromatograph (SRI Instruments, Torrance, CA) equipped with a thermal conductivity detector and a flame ionization detector.

\section{Effects of carbon additions}

The effects of labile $\mathrm{C}$ and soluble quinines on $\mathrm{Fe}(\mathrm{II})$ production rates were tested using 
anaerobic slurry incubations. Soil cores were homogenized by transect in an anaerobic glove bag and split into three treatments with three replicates each. Slurries were prepared in amber $125 \mathrm{~mL}$ serum vials with $20 \mathrm{~g}$ soil and deoxygenated water using a 2:1 water to soil ratio. The treatments were a control with no added $\mathrm{C}$, an addition of $5 \mathrm{mM}$ glucose, and an addition of 250 $\mu \mathrm{M}$ of the soluble quinone AQDS. Vials were sealed with butyl rubber septa, flushed with $\mathrm{N}_{2}$ and incubated for 36 hours. At 0 hours and 24 hours $1 \mathrm{~mL}$ of the slurry was sampled with a syringe and extracted for $\mathrm{Fe}$ (II) in $9 \mathrm{~mL}$ of $1 \mathrm{~N} \mathrm{HCl}$. Fe(II) was measured using the ferrozine assay described above.

\section{Results}

Abundance and activity of Fe cycling bacteria

Large numbers of culturable Fe(III)-reducing bacteria were detected in all forest soils, and cell densities generally increased from lower to upper elevation sites (Table 2). Cell densities were highest in the MRF with an average of $1.2 \times 10^{9}$ cells $\mathrm{g}^{-1}$ and lowest in the SWF-R soils with an average of $0.7 \times 10^{8}$ cells $\mathrm{g}^{-1}$. No significant differences in cell densities were observed between the two sampling dates. By comparing counts of culturable Fe(III)-reducers to direct counts of total microbial cells, Fe(III)-reducers were estimated to comprise between at least 1 to $6 \%$ of the total microbial community in these soils (Table 2). These estimates may be conservative, however, because most bacteria are unlikely to grow in culture using standard methods (Achtman and Wagner 2008).

The number of resident Fe(III)-reducing bacteria was significantly related to the rate of Fe(II) production in soil (Figure 1). Rates of Fe(II) production were highest in MRF soils and lowest in SWF soils (Table 2). Up to $44 \%$ of total $\mathrm{CO}_{2}$ production could be attributed to $\mathrm{Fe}$ (III) 
reduction based on the stoichiometric relationship of one mole of carbohydrate $\mathrm{C}$ oxidized for every 4 moles of Fe(II) produced (Table 2). Soil organic C concentrations were strongly positively correlated with $\mathrm{Fe}(\mathrm{II})$ production $\left(\mathrm{R}^{2}=0.72\right)$ (Figure 2).

The number of culturable lithotrophic Fe(II)-oxidizing bacteria was largest in soils with the highest Fe(II) production rates (Figure 3). Cell densities of Fe(II)-oxidizing bacteria ranged from 6.6 x $10^{5}$ cells g ${ }^{-1}$ in SWF-R soils to $1.1 \times 10^{8}$ cells g $^{-1}$ in MRF soils.

\section{Carbon additions}

$\mathrm{Fe}(\mathrm{II})$ production rates increased rapidly in nearly all soils upon addition of glucose and soluble quinone (Figure 4). Glucose addition increased rates of Fe(II) production by an average of 2.4-fold across all sites. The largest proportional increase in $\mathrm{Fe}(\mathrm{II})$ production with glucose addition occurred in soils with the lowest concentrations of soil organic C (Figure 4a). Soluble quinone addition increased rates of Fe(II) production by an average of 2.7-fold across all sites. No significant relationship was observed between the proportional increase in $\mathrm{Fe}$ (II) production with quinone addition and the concentration of soil organic C (Figure 4b).

\section{Trace gas production}

Anaerobic $\mathrm{CO}_{2}$ production was positively correlated with soil organic $\mathrm{C}\left(\mathrm{R}^{2}=0.68, \mathrm{P}<\right.$ 0.001), similar to the relationship between Fe(II) production and organic C (Figure 2). Log $\mathrm{Fe}(\mathrm{II})$ production increased linearly with anaerobic $\mathrm{CO}_{2}$ production $\left(\mathrm{R}^{2}=0.67, \mathrm{P}<0.001\right)$ (Figure 5a). A different pattern was observed for the relationship between $\mathrm{CO}_{2}$ production and $\mathrm{CH}_{4}$ production (Figure 5b). Methane production rates were small $\left(<1.5 \mathrm{nmol} \mathrm{g}^{-1}\right.$ day $\left.^{-1}\right)$ and did not increase until $\mathrm{CO}_{2}$ production rates approached $1.85 \mu \mathrm{mol} \mathrm{g}^{-1}$ day $^{-1}$. Thus substantial $\mathrm{Fe}$ (II) 
production and anaerobic $\mathrm{CO}_{2}$ respiration were observed where $\mathrm{CH}_{4}$ production was negligible. In soils with higher rates of $\mathrm{CO}_{2}$ production, however, $\mathrm{CH}_{4}$ production increased precipitously to rates up to $300 \mathrm{nmol} \mathrm{g}^{-1} \mathrm{day}^{-1}$.

\section{Discussion}

The large numbers of $\mathrm{Fe}(\mathrm{III})$-reducing and Fe(II)-oxidizing bacteria coupled with high rates of Fe(II) production indicate that Fe redox cycling by soil bacteria is an important biogeochemical process in upland tropical forests. The number of Fe cycling bacteria found in the upland soils in our study rival or exceed those found in wetland soils and lake-bottom sediments where $\mathrm{Fe}(\mathrm{III})$-reduction is more commonly identified as a dominant mode of microbial respiration (Roden and Wetzel 1996, Lowe et al. 2000, Kostka et al. 2002, Weiss et al. 2003, Kappler et al. 2004, Weber et al. 2006). Fe(III) reduction could account for more than a third of anoxic soil $\mathrm{CO}_{2}$ production in the mid and upper elevation tropical forests studied here (Table 2) with some individual transects exhibiting rates of Fe(III) reduction that could account for more than $50 \%$ of total $\mathrm{CO}_{2}$ production. These results suggest that $\mathrm{Fe}(\mathrm{III})$ reduction is a primary form of microbial respiration in these ecosystems.

Several factors probably account for the large number of Fe(III)-reducing bacteria found in these upland soils. The high NPP in these ecosystems supplies abundant labile organic C (reductant); this coupled with available amorphous Fe (oxidant) and perennially warm and wet conditions sustain large populations of Fe cycling bacteria. The spatial and temporal juxtaposition of oxidation and reduction processes in these soils (Silver et al. 1999) is likely to create ideal conditions for mutualistic interactions among Fe(III)-reducing and Fe(II)-oxidizing bacteria. $\mathrm{Fe}(\mathrm{II})$-oxidizing bacteria can effectively compete with abiotic $\mathrm{Fe}(\mathrm{II})$ oxidation for $\mathrm{O}_{2}$ 
under microaerobic conditions at redox interfaces where $\mathrm{O}_{2}$ is diffusion-limited (Neubauer et al. 2002, Emerson and Weiss 2004) and can enhance Fe(III) reduction by producing forms of Fe(III) favored by Fe(III) reducers (Sobolev and Roden 2001). Fe(II)-oxidizing bacteria also scavenge $\mathrm{O}_{2}$ and can create steep gradients in $\mathrm{O}_{2}$ that allow $\mathrm{Fe}(\mathrm{III})$ reducers to exist closer to the zone of Fe(II) oxidation. Stimulation of Fe(III) reduction by Fe(II)-oxidizing bacteria in turn increases $\mathrm{Fe}(\mathrm{II})$ production and may result in a positive feedback for Fe(II)-oxidizing bacteria, as indicated by the positive relationship between $\mathrm{Fe}(\mathrm{II})$ production rates and the abundance of $\mathrm{Fe}(\mathrm{II})$ oxidizing bacteria (Figure 3). In Luquillo soils, highly variable $\mathrm{O}_{2}$ concentrations in soil gas probably create steep gradients in redox at the soil aggregate ( $\mathrm{cm}$ to $\mathrm{mm}$ ) scale that would allow aerobic and anaerobic microorganisms to coexist in close proximity (Sexstone et al. 1985, Tokunaga et al. 2001). In addition, the presence of Fe-oxide root plaques in gleyed MRF soils indicates that plant oxygenation of the rhizosphere occurs and probably accelerates the resupply of Fe(III) for reduction (Emerson et al. 1999).

The repeated reduction and oxidation of Fe in tropical soils may fuel considerable organic C mineralization in humid tropical forests. In MWF and MRF soils, a substantial amount of decomposition must proceed via anaerobic pathways to account for high $\mathrm{Fe}(\mathrm{III})$ reduction rates and large numbers of $\mathrm{Fe}(\mathrm{III})$-reducing bacteria (Table 2). Low redox events are frequent in surface soils of these mid and upper elevation forests (Silver et al. 1999) and were found to be a strong selective force that structures soil bacterial communities at these sites (PettRidge and Firestone 2005). Strong correlations between microbial community structure, soil redox and decomposition parameters have been found in other upland humid forests (Schuur et al. 2001, Schwartz et al. 2007). A mechanistic understanding of decomposition and $\mathrm{CO}_{2}$ emissions in high-rainfall forests must consider anaerobic decomposition pathways that involve 
fermentation and respiratory $\mathrm{Fe}(\mathrm{III})$ reduction. In addition, manganese $(\mathrm{Mn})$ reduction may also contribute to decomposition because $\mathrm{Mn}(\mathrm{IV})$ is a strong anaerobic oxidant, and Mn reduction may support Fe(III)-reducing bacteria (many of which reduce Mn) when redox conditions do not favor Fe(III) reduction (Lovley et al. 2004). In Luquillo soils, Fe-oxides are far more abundant than Mn-oxides (Table 1) and substantial Fe(III) reduction begins almost immediately (within 24-hours) after the onset of anaerobic conditions, suggesting that $\mathrm{Fe}$ is probably a more important electron sink than $\mathrm{Mn}$ for anaerobic C oxidation.

Microbial Fe(III) reduction was rapidly stimulated by glucose and quinone additions suggesting that plants can have a direct influence on Fe(III) reduction dynamics via above- and belowground litter inputs and root exudation. Stimulation of $\mathrm{Fe}(\mathrm{III})$ reduction by glucose and quinone compounds constitutes a mechanism by which plants may directly influence rates of $\mathrm{Fe}(\mathrm{III})$ reduction in upland soils, that is by supplying labile $\mathrm{C}$ or soluble electron shuttles to soil microbial communities. Root exudates contain simple sugars and organic acids that are favored substrates for Fe(III) reducers (Lovley et al. 2004), and may fuel the consumption of more energetically-favorable electron acceptors $\left(\mathrm{O}_{2}, \mathrm{NO}_{3}{ }^{-}, \mathrm{Mn}\right)$ in the rhizosphere to promote $\mathrm{Fe}(\mathrm{III})$ reducing conditions. Roots may also stimulate Fe(III) reduction by producing compounds that contain quinone moeties that serve as electron shuttles between microbial cells and Fe(III) oxide surfaces (King and Garey 1999, Nevin and Lovley 2002, Weiss et al. 2004, Fimmen et al. 2008). If high-rainfall forest plants stimulate Fe(III) reduction in their rhizospheres, they may directly manipulate the $\mathrm{P}$ and $\mathrm{C}$ sorption capacity of rhizosphere Fe(III) oxides over short periods of time. Bacterial Fe(III) reduction can release P from Fe(III) oxides into bioavailable forms (Peretyazhko and Sposito 2005, Chácon et al. 2006, Liptzin and Silver 2009). Manipulation of microbial Fe redox dynamics may be a mechanism by which tropical forest plants increase 
access to P sorbed or occluded by Fe(III) oxides. Similarly, stimulation of Fe(III) reduction by plant activity may release organic compounds that are bound to Fe(III) minerals and increase their susceptibility to decomposition and leaching.

Competitive interactions between Fe(III)-reducing bacteria and methanogenic archaea can suppress $\mathrm{CH}_{4}$ emissions from soils and sediments. Fe(III)-reducing bacteria can outcompete methanogenic archaea for acetate and hydrogen, which are important electron sources for methanogenesis (Lovley and Phillips 1987, Achtnich et al. 1995, Roden and Wetzel 1996, Frenzel et al. 1999, Chidthaisong and Conrad 2000). Consequently, Fe(III) reducers can suppress $\mathrm{CH}_{4}$ emissions from upland tropical soils (Teh et al. 2008). In addition, Fe(III)-reducing bacteria have a wide metabolic diversity and many are facultative anaerobes (Lovley et al. 2004), providing another competitive advantage over strictly anaerobic methanogens in dynamic redox environments. Our results suggest that under anaerobic conditions the extent of competitive suppression depends on $\mathrm{C}$ availability and hence should vary among sites. In soils with less than $7 \%$ organic $\mathrm{C}, \mathrm{Fe}(\mathrm{II})$ production was positively correlated with anaerobic $\mathrm{CO}_{2}$ production, but $\mathrm{CH}_{4}$ production was not (Figure 5). Results from the $\mathrm{C}$ addition experiment indicate that competition by Fe(III)-reducing bacteria is likely to be most intense in soils with lower organic C contents. Competition for this limiting resource by Fe(III)-reducing bacteria may explain why $\mathrm{CH}_{4}$ production was suppressed in lower $\mathrm{C}$ soils at the onset of anaerobic conditions. Where concentrations of organic $\mathrm{C}$ were high, however, both $\mathrm{Fe}(\mathrm{II})$ and $\mathrm{CH}_{4}$ production rates were high (Figure 5). Competitive inhibition of methanogens by $\mathrm{Fe}(\mathrm{III})$ reducers relaxes where $\mathrm{C}$ is abundant (Lovley and Phillips 1987).

The dramatic increase in $\mathrm{CH}_{4}$ production in high $\mathrm{C}$ sites may signal a threshold effect, where competitive inhibition of methanogens by Fe(III)-reducing bacteria saturates above a 
certain level of $\mathrm{C}$ availability. Where this occurs $\mathrm{CH}_{4}$ production increases precipitously. Competition for oxygen between methanotrophic bacteria and Fe(II) oxidation may also constrain $\mathrm{CH}_{4}$ flux where $\mathrm{O}_{2}$ is limiting and $\mathrm{Fe}(\mathrm{II})$ is abundant (van Bodegom et al. 2001). Recent satellite data suggest that some tropical regions are a source of atmospheric methane (Frankenberg et al. 2005), although the mechanisms responsible are poorly understood. Microbial competition for resources may create biogeochemical thresholds that are critical for modeling $\mathrm{CH}_{4}$ emissions from wet tropical forests and other environments where $\mathrm{Fe}(\mathrm{III})$ reduction is an important process (van Bodegom et al. 2001, Xu et al. 2007). Soil organic C pools in humid tropical forests are sensitive to climate and land-use (Silver 1998), and are likely to change in the coming decades (Scholze et al. 2006). In light of these potential changes, regional and global models of greenhouse gas dynamics should consider the degree to which $\mathrm{Fe}(\mathrm{III})$ reduction suppresses $\mathrm{CH}_{4}$ emissions under different soil conditions.

The activities of Fe cycling bacterial communities can impact forest productivity and $\mathrm{C}$ cycling in upland tropical forests. Fe(III)-reducing and Fe(II)-oxidizing bacteria are highly sensitive to concentrations of soil $\mathrm{O}_{2}$ and $\mathrm{C}$; thus small changes in rainfall and soil $\mathrm{C}$ in humid tropical forests may translate into large changes in Fe redox cycling with immediate consequences to nutrient cycling, $\mathrm{C}$ storage and trace gas emissions in these ecosystems.

\section{Acknowledgements}

We thank Jeff Bird, Paul Brooks, Julian Fortney, Don Herman and Forest Kaser for laboratory assistance. The USDA International Institute for Tropical Forestry (IITF) provided logistical and infrastructural support for field research. A National Science Foundation (NSF) Graduate Research Fellowship and NASA Earth System Science Fellowship NGT5-30463 supported 
E.A.D. NSF grant DEB-0543558 and a grant from the Mellon Foundation to M.K.F and W.L.S funded this work. Support was also provided by NSF grant DEB-0218039 to the Institute of Tropical Ecosystem Studies, UPR, and USDA-IITF as part of the Long-Term Ecological Research Program in the Luquillo Experimental Forest. MF is partially funded by the U.S. DOE under Contract No. DE-AC02-05CH11231.

\section{Literature Cited}

Achtnich, C., F. Bak, and R. Conrad. 1995. Competition for Electron-Donors among Nitrate Reducers, Ferric Iron Reducers, Sulfate Reducers, and Methanogens in Anoxic Paddy Soil. Biology and Fertility of Soils 19:65-72.

Achtman, M. and M. Wagner. 2008. Microbial diversity and the genetic nature of microbial species. Nature Reviews Microbiology 6:431-440.

Brown, S., A. E. Lugo, S. Silander, and L. L. 1983. Research history and opportunities in the Luquillo Experimental Forest. U.S.D.A. Forest Service Southern Forest Experimental Station. General Technical Report SO-44, New Orleans, LA.

Canfield, D. E., B. Thamdrup, and J. W. Hansen. 1993. The Anaerobic Degradation of OrganicMatter in Danish Coastal Sediments - Iron Reduction, Manganese Reduction, and Sulfate Reduction. Geochimica et Cosmochimica Acta 57:3867-3883.

Chácon, N., W. L. Silver, E. A. Dubinsky, and D. F. Cusack. 2006. Iron reduction and soil phosphorus solubilization in humid tropical forests soils: The roles of labile carbon pools and an electron shuttle compound. Biogeochemistry 78:67-84. 
Chidthaisong, A., and R. Conrad. 2000. Turnover of glucose and acetate coupled to reduction of nitrate, ferric iron and sulfate and to methanogenesis in anoxic rice field soil. Fems Microbiology Ecology 31:73-86.

Emerson, D., and C. Moyer. 1997. Isolation and characterization of novel iron-oxidizing bacteria that grow at circumneutral pH. Applied and Environmental Microbiology 63:4784-4792.

Emerson, D., and J. V. Weiss. 2004. Bacterial iron oxidation in circumneutral freshwater habitats: Findings from the field and the laboratory. Geomicrobiology Journal 21:405414.

Emerson, D., J. V. Weiss, and J. P. Megonigal. 1999. Iron-oxidizing bacteria are associated with ferric hydroxide precipitates (Fe-plaque) on the roots of wetland plants. Applied and Environmental Microbiology 65:2758-2761.

Fimmen, R.L., D.D. Richter Jr., D. Vasudevan, M.A. Williams and L.T. West. 2008. Rhizogenic Fe-C redox cycling: a hypothetical biogeochemical mechanism that drives crustal weathering in upland soils. Biogeochemistry 87:127-141.

Frankenberg, C., J. F. Meirink, M. van Weele, U. Platt, and T. Wagner. 2005. Assessing methane emissions from global space-borne observations, Science 308:1010-1014.

Frenzel, P., U. Bosse, and P. H. Janssen. 1999. Rice roots and methanogenesis in a paddy soil: ferric iron as an alternative electron acceptor in the rooted soil. Soil Biology \& Biochemistry 31:421-430.

Herbert, D. A., and J. H. Fownes. 1995. Phosphorus Limitation of Forest Leaf-Area and Net Primary Production on a Highly Weathered Soil. Biogeochemistry 29:223-235. Holdridge, L. R. 1967. Life Zone Ecology. Tropical Science Center, San Jose, Costa Rica. 
Huffaker, L. 2002. Soil Survey of Caribbean National Forest and Luquillo Experimental Forest, Commonwealth of Puerto Rico. US Department of Agriculture, Natural Resource Conservation Service, Washington, D.C.

Jobbagy, E. G., and R. B. Jackson. 2000. The vertical distribution of soil organic carbon and its relation to climate and vegetation. Ecological Applications 10:423-436.

Kappler, A., M. Benz, B. Schink, and A. Brune. 2004. Electron shuttling via humic acids in microbial iron(III) reduction in a freshwater sediment. FEMS Microbiology Ecology 47:85-92.

King, G. M., and M. A. Garey. 1999. Ferric tron reduction by bacteria associated with the roots of freshwater and marine macrophytes. Applied and Environmental Microbiology 65:4393-4398.

Klee, A. J. 1996. Most Probable Number Calculator version 4.04. in. U.S. Environmental Protection Agency, Risk Reduction Engineering Laboratory, Cincinnati, $\mathrm{OH}$.

Kostka, J. E., B. Gribsholt, E. Petrie, D. Dalton, H. Skelton, and E. Kristensen. 2002. The rates and pathways of carbon oxidation in bioturbated saltmarsh sediments. Limnology and Oceanography 47:230-240.

Küsel, K., C. Wagner, T. Trinkwalter, A. S. Gossner, R. Baumler, and H. L. Drake. 2002. Microbial reduction of Fe(III) and turnover of acetate in Hawaiian soils. FEMS Microbiology Ecology 40:73-81.

Liptzin, D., and W. L. Silver. 2009. Effects of carbon additions on iron reduction and phosphorus availability in a humid tropical forest soil. Soil Biology \& Biochemistry 41:1696-1702. 
Loeppert, R. H., and W. P. Inskeep. 1996. Iron. Pages 639-665 in D. L. Sparks, editor. Methods of soil analysis. Part 3: Chemical methods. Soil Science Society of America, Madison, WI.

Lovley, D. R., J. D. Coates, E. L. BluntHarris, E. J. P. Phillips, and J. C. Woodward. 1996. Humic substances as electron acceptors for microbial respiration. Nature 382:445-448.

Lovley, D. R., D. E. Holmes, and K. P. Nevin. 2004. Dissimilatory Fe(III) and Mn(IV) reduction. Pages 219-286 in Advances in Microbial Physiology, Vol. 49.

Lovley, D. R., and E. J. P. Phillips. 1987. Competitive Mechanisms for Inhibition of Sulfate Reduction and Methane Production in the Zone of Ferric Iron Reduction in Sediments. Applied and Environmental Microbiology 53:2636-2641.

Lowe, K. L., T. J. Dichristina, A. N. Roychoudhury, and P. Van Cappellen. 2000. Microbiological and geochemical characterization of microbial Fe(III) reduction in salt marsh sediments. Geomicrobiology Journal 17:163-176.

Miller, A. J., E. A. G. Schuur, and O. A. Chadwick. 2001. Redox control of phosphorus pools in Hawaiian montane forest soils. Geoderma 102:219-237.

Neubauer, S. C., D. Emerson, and J. P. Megonigal. 2002. Life at the energetic edge: Kinetics of circumneutral iron oxidation by lithotrophic iron-oxidizing bacteria isolated from the wetland-plant rhizosphere. Applied and Environmental Microbiology 68:3988-3995.

Neubauer, S. C., K. Givler, S. K. Valentine, and J. P. Megonigal. 2005. Seasonal patterns and plant-mediated controls of subsurface wetland biogeochemistry. Ecology 86:3334-3344.

Nevin, K. P., and D. R. Lovley. 2002. Mechanisms for Fe(III) oxide reduction in sedimentary environments. Geomicrobiology Journal 19:141-159. 
Patrick, W. H., and R. A. Khalid. 1974. Phosphate Release and Sorption by Soils and Sediments - Effect of Aerobic and Anaerobic Conditions. Science 186:53-55.

Peretyazhko, T., and G. Sposito. 2005. Iron(III) reduction and phosphorous solubilization in humid tropical forest soils. Geochimica et Cosmochimica Acta 69:3643-3652.

Pett-Ridge, J., and M. K. Firestone. 2005. Redox fluctuation structures microbial communities in a wet tropical soil. Applied and Environmental Microbiology 71:6998-7007.

Pfennig, N., and H. G. Trüper. 1992. The family Chromatiaceae. Pages 3200-3221 in A. Balows, H. G. Trüper, M. Dworkin, W. Harder, and K. H. Schleifer, editors. The Prokaryotes. Springer, New York, NY.

Reyes, I., and J. Torrent. 1997. Citrate-ascorbate as a highly selective extractant for poorly crystalline iron oxides. Soil Science Society of America Journal 61:1647-1654.

Roden, E. E., and R. G. Wetzel. 1996. Organic carbon oxidation and suppression of methane production by microbial $\mathrm{Fe}(\mathrm{III})$ oxide reduction in vegetated and unvegetated freshwater wetland sediments. Limnology and Oceanography 41:1733-1748.

Sanchez, P. 1976. Properties and management of soils in the tropics. John Wiley \& Sons, New York.

Saugier, B., J. Roy, and H. A. Mooney. 2002. Estimations of global terrestrial productivity: converging toward a single number? in J. Roy, B. Saugier, and H. A. Mooney, editors. Terrestrial Global Productivity. Academic Press, New York, NY.

Scatena, F. N. 1989. An introduction to the physiography and history of the Bisley Experimental Watersheds in the Luquillo Mountains of Puerto Rico. U.S.D.A. Forest Service Southern Forest Experimental Station. General Technical Report SO-72, New Orleans, LA. 
Scholze, M., W. Knorr, N. W. Arnell, and I. C. Prentice. 2006. A climate-change risk analysis for world ecosystems. Proceedings of the National Academy of Sciences of the United States of America 103:13116-13120.

Schuur, E.A.G., O.A. Chadwick and P.A. Matson. Carbon cycling and soil carbon storage in mesic to west Hawaiian montane forests. Ecology 82:3182-3196

Schwartz, E., K.L. Adair and E.A. Schuur. Bacterial community structure correlates with decomposition parameters along a Hawaiian precipitation gradient. Soil Biology and Biochemistry 39:2164-2167.

Schwertmann, U., and R. M. Cornell. 2000. Iron oxides in the laboratory: Preparation and characterization. John Wiley \& Sons, New York, NY.

Sexstone, A. J., N. P. Revsbech, T. B. Parkin, and J. M. Tiedje. 1985. Direct Measurement of Oxygen Profiles and Denitrification Rates in Soil Aggregates. Soil Science Society of America Journal 49:645-651.

Silver, W. L. 1998. The potential effects of elevated CO2 and climate change on tropical forest soils and biogeochemical cycling. Climatic Change 39:337-361.

Silver, W. L., A. E. Lugo, and M. Keller. 1999. Soil oxygen availability and biogeochemistry along rainfall and topographic gradients in upland wet tropical forest soils. Biogeochemistry 44:301-328.

Sobolev, D., and E. E. Roden. 2001. Suboxic deposition of ferric iron by bacteria in opposing gradients of $\mathrm{Fe}(\mathrm{II})$ and oxygen at circumneutral pH. Applied and Environmental Microbiology 67:1328-1334.

Stookey, L. L. 1970. Ferrozine - a New Spectrophotometric Reagent for Iron. Analytical Chemistry 42:779-\&. 
Teh, Y. A., W. L. Silver, E. A. Dubinsky, and C. M. Carlson. 2008. Suppression of methanogenesis by dissimilatory Fe(III)-reducing bacteria in tropical rain forest soils: implications for ecosystem methane flux. Global Change Biology 14:413-422.

Tokunaga, T. K., J. M. Wan, M. K. Firestone, T. C. Hazen, E. Schwartz, S. R. Sutton, and M. Newville. 2001. Chromium diffusion and reduction in soil aggregates. Environmental Science \& Technology 35:3169-3174.

Torn, M. S., S. E. Trumbore, O. A. Chadwick, P. M. Vitousek, and D. M. Hendricks. 1997. Mineral control of soil organic carbon storage and turnover. Nature 389:170-173.

Uehara, G., and G. Gillman. 1981. The mineralogy, chemicstry, and physics of tropical soils with variable charge clays. Westview Press, Boulder.

van Bodegom, P. M., R. Wassman, and T. M. Metra-Corton. 2001. A process-based model for methane emission predictions from flooded rice paddies. Global Biogeochemical Cycles 15:247-263.

Vitousek, P. M., and H. Farrington. 1997. Nutrient limitation and soil development: Experimental test of a biogeochemical theory. Biogeochemistry 37:63-75.

Wagai, R., and L. M. Mayer. 2007. Sorptive stabilization of organic matter in soils by hydrous iron oxides. Geochimica et Cosmochimica Acta 71:25-35.

Weber, K. A., M. M. Urrutia, P. F. Churchill, R. K. Kukkadapu, and E. E. Roden. 2006. Anaerobic redox cycling of iron by freshwater sediment microorganisms. Environmental Microbiology 8:100-113.

Weiss, J. V., D. Emerson, S. M. Backer, and J. P. Megonigal. 2003. Enumeration of Fe(II)oxidizing and $\mathrm{Fe}(\mathrm{III})$-reducing bacteria in the root zone of wetland plants: Implications for a rhizosphere iron cycle. Biogeochemistry 64:77-96. 
Weiss, J. V., D. Emerson, and J. P. Megonigal. 2004. Geochemical control of microbial Fe(III) reduction potential in wetlands: comparison of the rhizosphere to non-rhizosphere soil. FEMS Microbiology Ecology 48:89-100.

White, A. F., A. E. Blum, M. S. Schulz, D. V. Vivit, D. A. Stonestrom, M. Larsen, S. F. Murphy, and D. Eberl. 1998. Chemical weathering in a tropical watershed, Luquillo mountains, Puerto Rico: I. Long-term versus short-term weathering fluxes. Geochimica et Cosmochimica Acta 62:209-226.

Widdel, F., and F. Bak. 1992. Gram-negative mesophilic sulfate-reducing bacteria. in A. Balows, H. G. Trüper, M. Dworkin, W. Harder, and K. H. Schleifer, editors. The Prokaryotes. Springer, New York, NY.

Xu, S. P., P. R. Jaffe, and D. L. Mauzerall. 2007. A process-based model for methane emission from flooded rice paddy systems. Ecological Modelling 205:475-491. 
Table 1. Site characteristics. Letters indicate significant differences between sites (Tukey test, $\mathrm{P}<0.05$ ). Values in parentheses are standard errors among transects.

\begin{tabular}{|c|c|c|c|c|c|c|c|c|c|c|}
\hline Site & $\begin{array}{l}\text { Elev. } \\
\text { (masl) }\end{array}$ & $\begin{array}{l}\text { MAP } \\
(\mathrm{mm})\end{array}$ & $\mathrm{pH}$ & $\begin{array}{l}\mathrm{Fe}_{\mathrm{PC}} \\
\left(\mathrm{mg} \mathrm{g}^{-1}\right)\end{array}$ & $\begin{array}{l}\mathrm{Fe}_{\mathrm{TOT}} \\
\left(\mathrm{mg} \mathrm{g}^{-1}\right)\end{array}$ & $\mathrm{Fe}_{\mathrm{PC}} / \mathrm{Fe}_{\text {TOт }}$ & $\begin{array}{l}\mathrm{Mn}_{\mathrm{TOT}} \\
\left(\mathrm{mg} \mathrm{g}^{-1}\right)\end{array}$ & $\mathrm{C}(\%)$ & $\mathrm{N}(\%)$ & $\begin{array}{l}\text { Sand-Silt- } \\
\text { Clay }(\%)\end{array}$ \\
\hline SWF-R & 350 & 3500 & $4.8(0.1)^{\mathrm{b}}$ & $7.4 \quad(0.7)$ & $57.5(2.7)^{b}$ & $0.13(0.02)^{\mathrm{a}}$ & $0.75(0.09)^{\mathrm{a}}$ & $2.6(0.3)^{\mathrm{a}}$ & $0.21(0.01)^{\mathrm{a}}$ & $14-35-52$ \\
\hline MWF-4 & 780 & 4200 & $5.1(0.2)^{\mathrm{ab}}$ & $9.6 \quad(2.3)$ & $21.7(6.2)^{\mathrm{a}}$ & $0.51(0.13)^{b}$ & $0.07(0.01)^{\mathrm{b}}$ & $7.4(2.0)^{\mathrm{a}}$ & $0.31(0.06)^{\mathrm{a}}$ & $63-18-18$ \\
\hline MRF & 950 & 5000 & $5.0(0.2)^{\mathrm{ab}}$ & 10.5 (1.9) & $19.2(2.1)^{\mathrm{a}}$ & $0.54(0.04)^{b}$ & $0.07(0.01)^{b}$ & $12.9(0.8)^{b}$ & $0.54(0.04)^{b}$ & $29-51-19$ \\
\hline
\end{tabular}

SWF-V = subtropical wet forest valley; SWF-R = subtropical wet forest ridge; MWF = montane wet forest; MRF = montane rain forest; MAP = mean annual precipitation; $\mathrm{PC}=$ poorly crystalline oxides; $\mathrm{TOT}=$ total oxides. 
Table 2. Abundance and activity of soil $\mathrm{Fe}(\mathrm{III})$-reducing bacteria. $\mathrm{Fe}(\mathrm{II})$ and $\mathrm{CO}_{2}$ production were measured in 24-hour anaerobic incubations. Letters indicate significant differences between sites (Tukey test, $\mathrm{P}<0.05)$. Values in parentheses are standard errors among transects.

\begin{tabular}{|c|c|c|c|c|}
\hline Site & $\begin{array}{l}\text { Number Fe(III)- } \\
\text { reducers } \\
\left(10^{8} \text { cells g }{ }^{-1}\right)\end{array}$ & $\begin{array}{l}\text { Rel. abundance } \\
\text { Fe(III)-reducers } \\
\text { (\% total cells) }\end{array}$ & $\begin{array}{l}\mathrm{Fe}(\mathrm{II}) \\
\text { production } \\
\left(\mu \mathrm{mol} \mathrm{g}{ }^{-1} \mathrm{day}^{-1}\right)\end{array}$ & $\begin{array}{l}\% \mathrm{CO}_{2} \text { from } \\
\mathrm{Fe}(\mathrm{II}) \text { production }\end{array}$ \\
\hline SWF-V & $0.8 \quad(0.4)^{\mathrm{a}}$ & $0.7(0.3)^{\mathrm{a}}$ & $0.7(0.3)^{\mathrm{ab}}$ & $11.2(4.1)^{\mathrm{ab}}$ \\
\hline SWF-R & $0.7(0.2)^{\mathrm{a}}$ & $1.4(0.6)^{\mathrm{ab}}$ & $0.1(0.04)^{\mathrm{a}}$ & $3.6(0.8)^{\mathrm{a}}$ \\
\hline MWF-1 & $2.1(1.4)^{\mathrm{ab}}$ & $1.5(1.0)^{\mathrm{ab}}$ & $0.8(0.2)^{\mathrm{abc}}$ & $13.5(3.0)^{\mathrm{ab}}$ \\
\hline MWF-4 & $6.5(1.7)^{b c}$ & $5.0(1.6)^{\mathrm{ab}}$ & $3.2(1.6)^{b c}$ & $36.6(16.0)^{\mathrm{ab}}$ \\
\hline MRF & $11.5(0.2)^{\mathrm{c}}$ & $5.7(1.0)^{\mathrm{b}}$ & $3.7(0.7)^{\mathrm{c}}$ & $43.8(7.5)^{\mathrm{b}}$ \\
\hline
\end{tabular}

SWF-V = subtropical wet forest valley; SWF-R = subtropical wet forest ridge;

$\mathrm{MWF}=$ montane wet forest $\mathrm{MRF}=$ montane rain forest. 


\section{Figure Legends}

Figure 1. Number of $\mathrm{Fe}(\mathrm{III})$-reducing bacteria versus $\mathrm{Fe}(\mathrm{II})$ production rates $\left(\mathrm{R}^{2}=0.59, \mathrm{P}<\right.$ $0.001)$.

Figure 2. Fe(II) production rates as a function of soil organic C. Fe(II) production (nmol g ${ }^{-1}$ day $\left.^{-1}\right)$ was modeled by organic $C(\%) \times 0.12+2.16\left(R^{2}=0.72, P<0.001\right)$.

Figure 3. Number of Fe(II)-oxidizing bacteria versus $\mathrm{Fe}(\mathrm{II})$ production rates $\left(\mathrm{R}^{2}=0.97, \mathrm{P}=\right.$ $0.002)$.

Figure 4. Stimulation of Fe(II) production by glucose (a) and the soluble quinone AQDS (b) as a function of soil organic $\mathrm{C}(\%)$. Data points above the dashed line indicate $\mathrm{Fe}(\mathrm{II})$ production rates that exceed the control (no $\mathrm{C}$ addition). Both glucose and quinone significantly increased $\mathrm{Fe}(\mathrm{II})$ production rates across all soils (paired t-test, $\mathrm{P}<0.001$ ). The negative relationship between soil organic $\mathrm{C}$ and increase in $\mathrm{Fe}(\mathrm{II})$ production by glucose addition was significant $\left(\mathrm{R}^{2}\right.$ $=0.37, \mathrm{P}=0.016)$. There was no significant relationship between soil organic $\mathrm{C}$ and increase in Fe(II) production by quinone addition.

Figure 5. Rates of anaerobic $\mathrm{CO}_{2}$ production versus $\mathrm{Fe}(\mathrm{II})$ production (a) and $\mathrm{CH}_{4}$ production (b) in individual soil cores. Anaerobic $\mathrm{CO}_{2}$ production was significantly related to $\mathrm{Fe}$ (II) production $\left(\mathrm{R}^{2}=0.67, \mathrm{P}<0.001\right)$ and $\mathrm{CH}_{4}$ production $\left(\mathrm{R}^{2}=0.55, \mathrm{P}<0.001\right)$. 
Figure 1

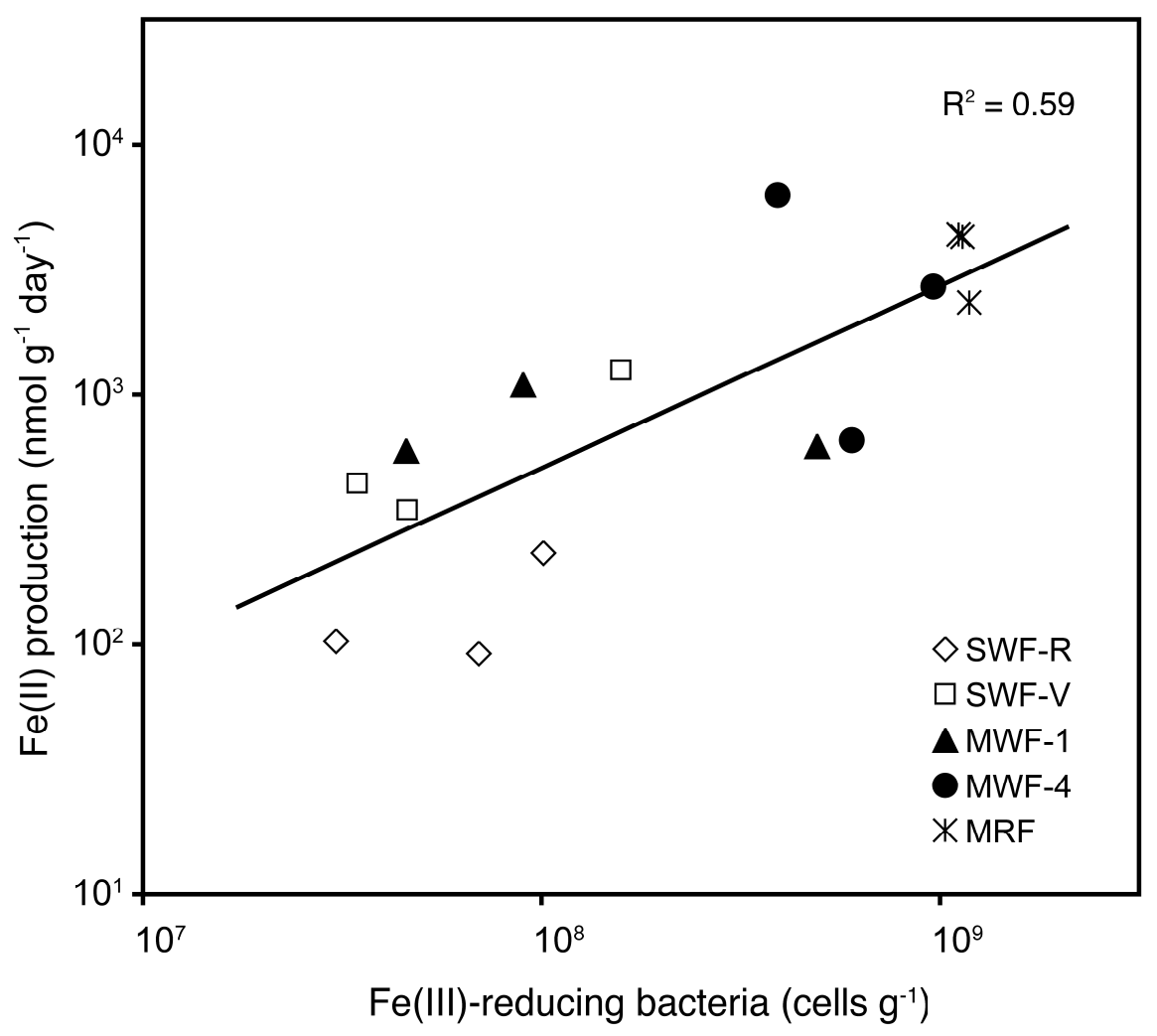


Figure 2

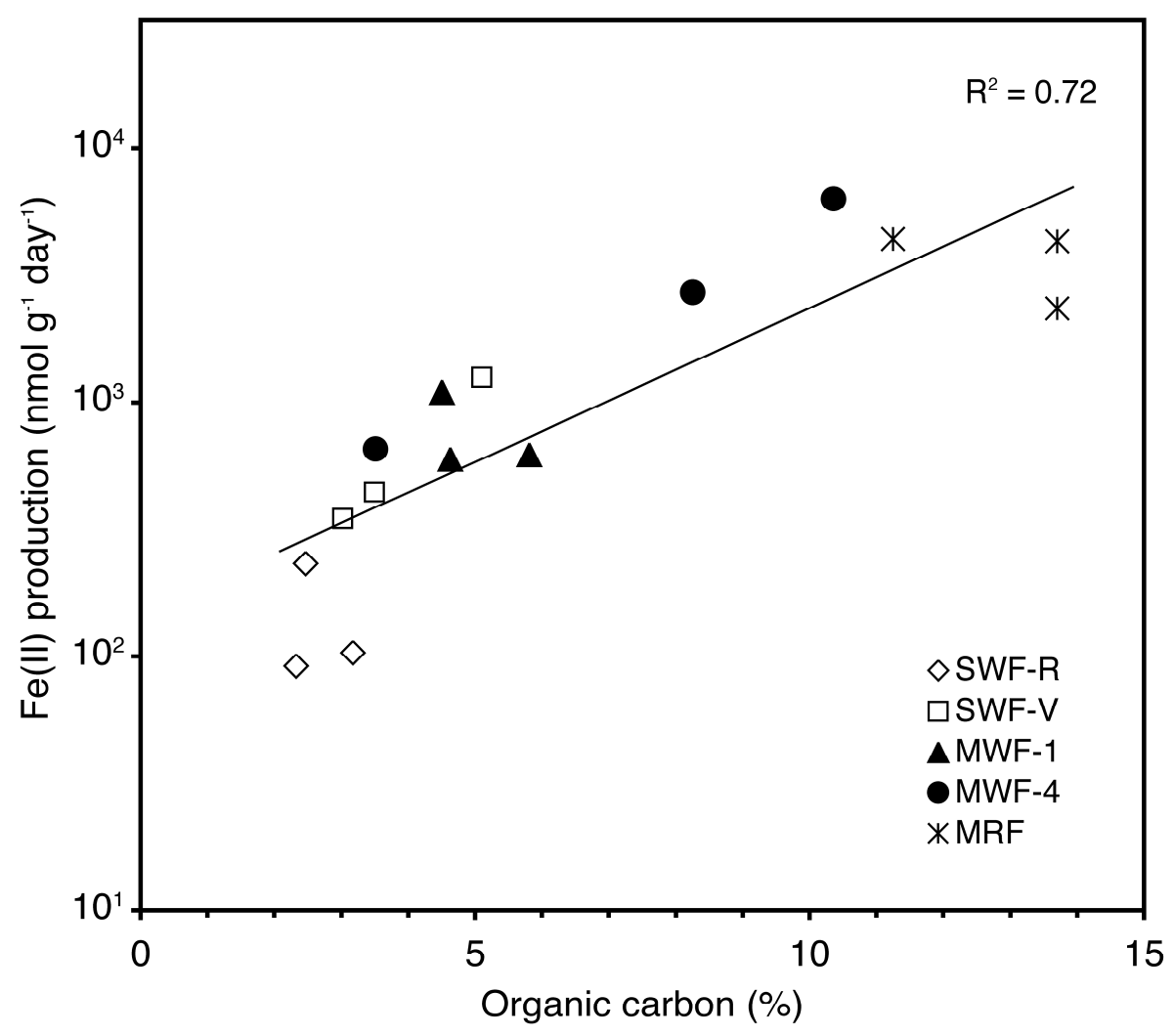


Figure 3

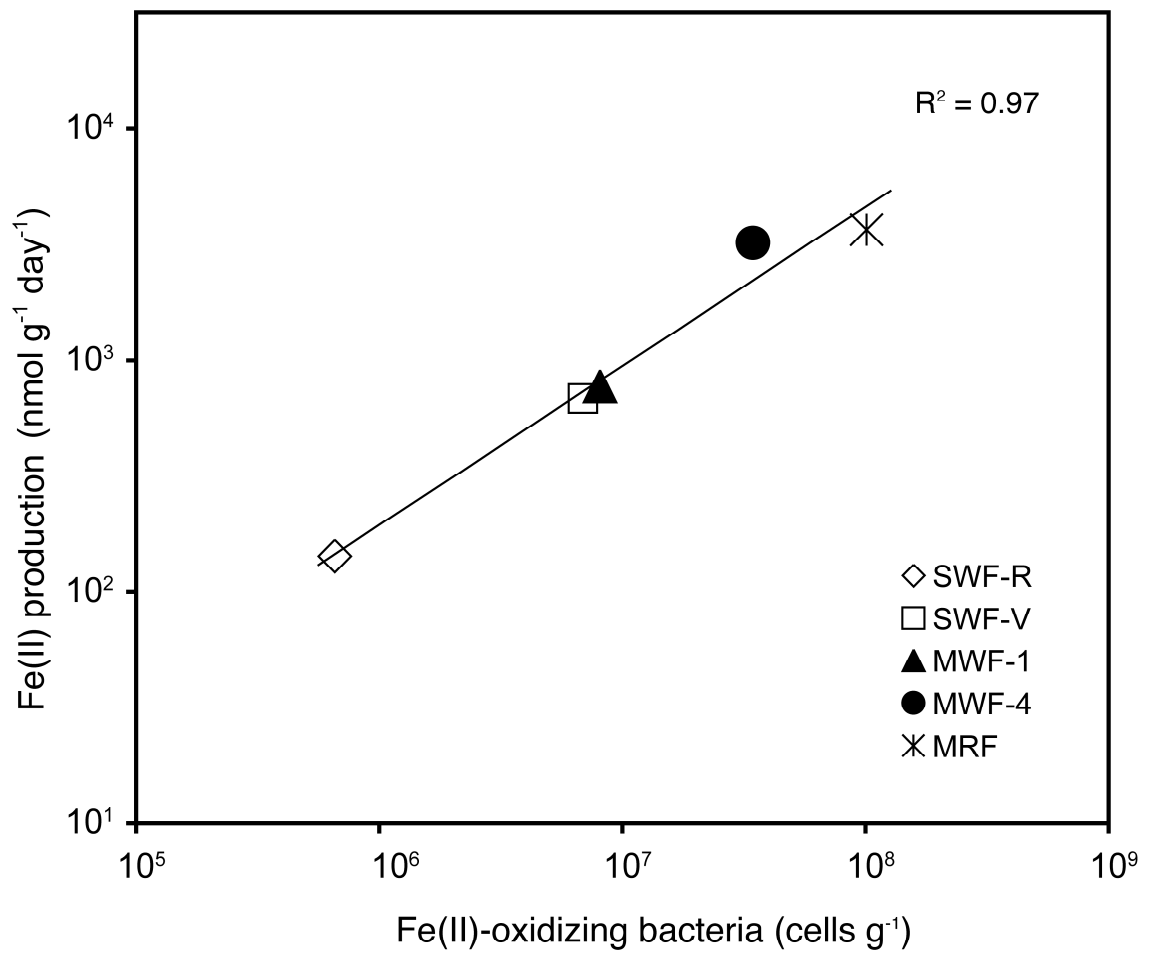


Figure 4
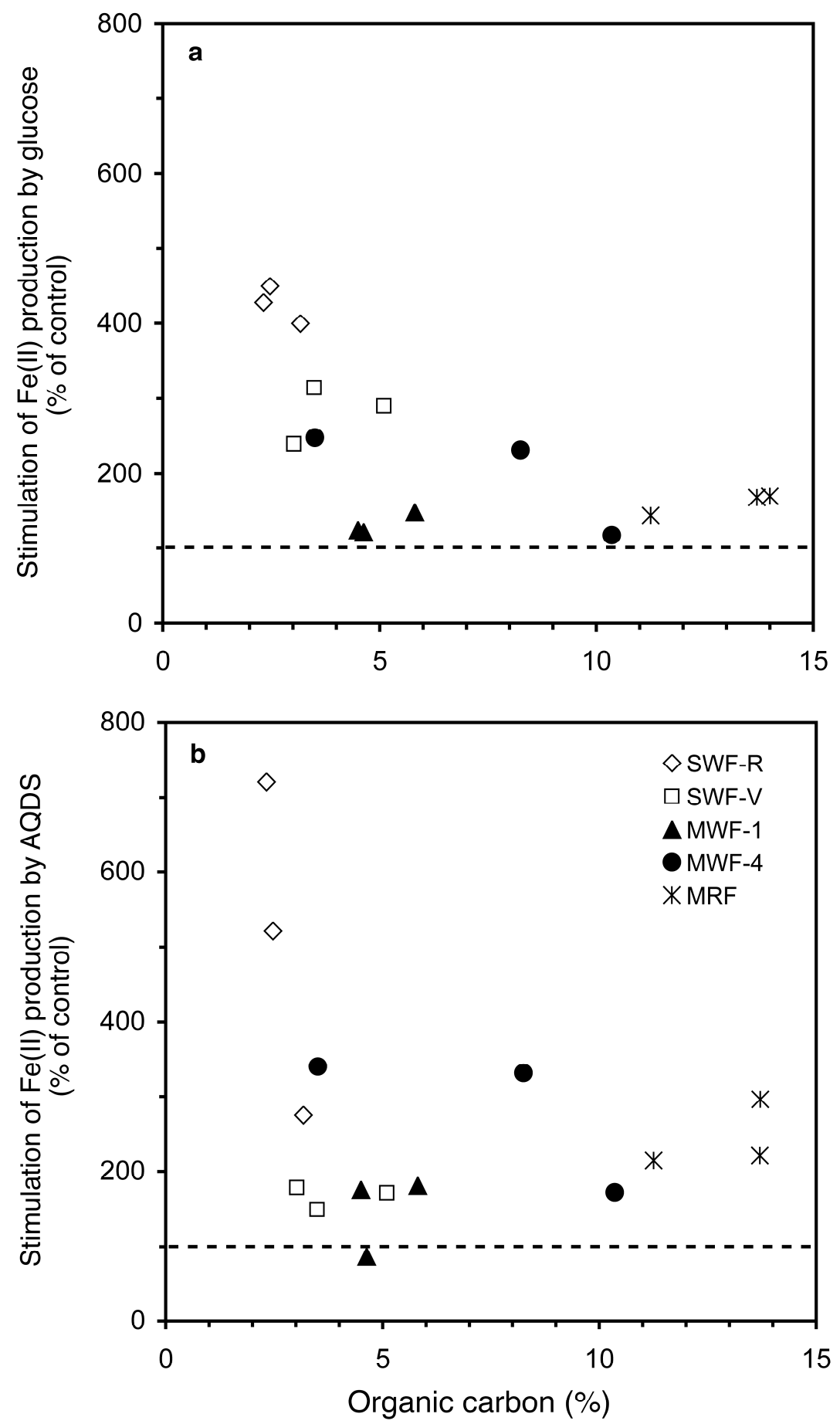
Figure 5
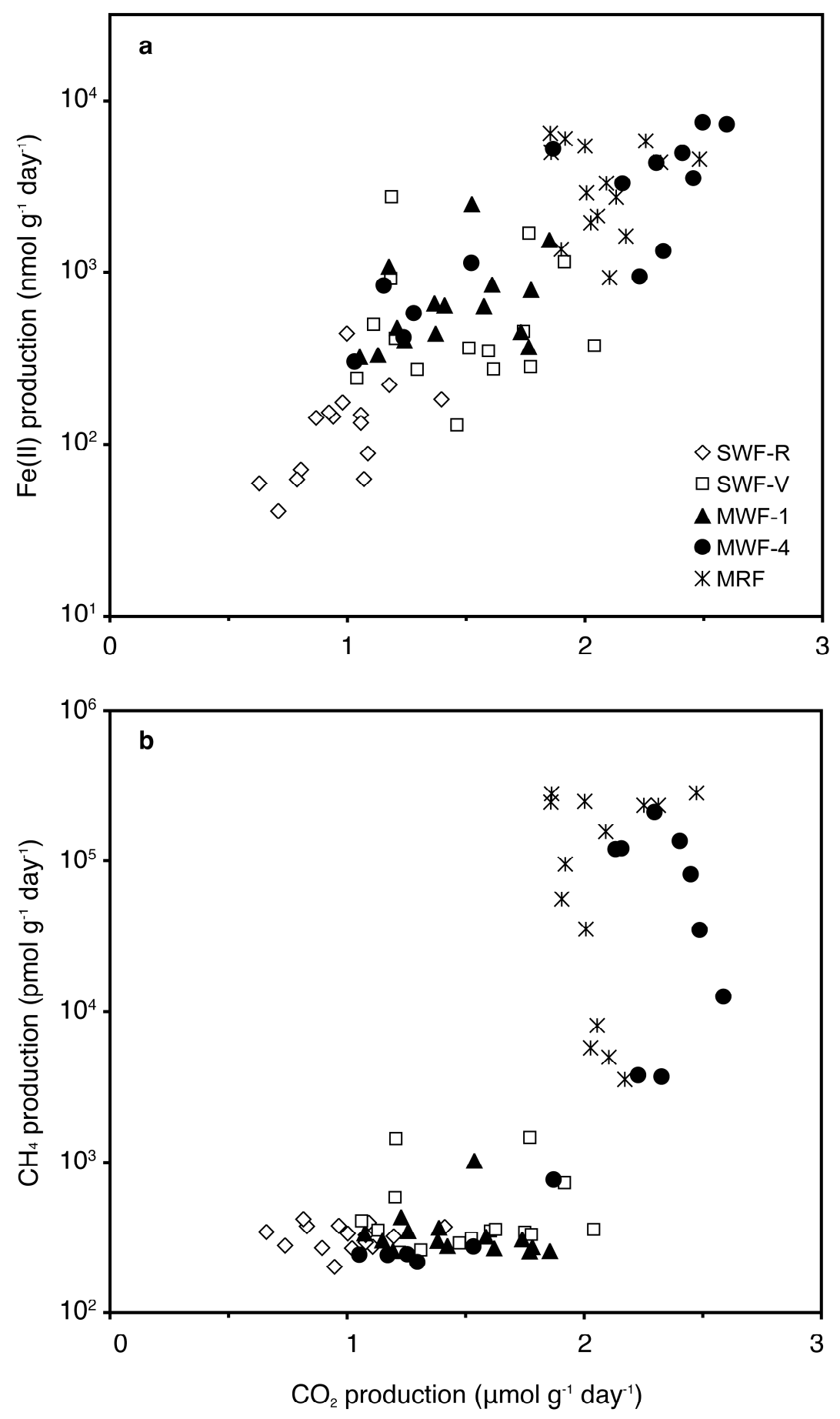